\title{
Nesting of marine turtles on the Egyptian beaches of the Red Sea
}

\author{
Mahmoud H. Hanafy
}

Department of Marine Science, Faculty of Science, Suez Canal University, Ismailia, Egypt.

\section{ABSTRACT}

Nesting of two species; the hawksbill Eretmochelys imbricate and the green turtle Chelonia mydas on the Egyptian beaches of the Red Sea were studied. The nesting seasons were extended from May to July with a peak in June for the hawksbill and from June to August with a peak in July for the green turtle. Separate nesting grounds for both species with minimum overlap were observed. In total, 38 beaches were surveyed and classified according to the density of nests and tracks. Out of the 38 surveyed beaches, 8 totally offshore beaches were classified as valuable nesting grounds for the hawksbill and 14 beaches for green turtles (inshore and offshore sites).

The quantitative estimation of nesting level (i.e. density of nests and tracks) indicated that there are 3 most valuable nesting offshore beaches for the hawksbill and 8 sites for the green turtle ( 3 inshore and 5 offshore). During 2001-2008, the nesting activities were estimated quantitatively based on the density of true and false nests as well as the dimensions of tracks, nests and female turtle at the most valuable nesting sites (Small and Big Giftun Islands for hawksbill, Zabarged Island, Ras Bagdadi and Umm El-Abas, for green turtles). Hatching percentages, clutch sizes as well as egg and hatchling sizes for both species were estimated.

Key words: Red Sea, marine turtles, turtle nesting, conservation

\section{INTRODUCTION}

Five species of marine turtles have been observed in the Egyptian Red Sea: the green turtle (Chelonia mydas), the hawksbill (Eretmochelys imbricata), the loggerhead (Caretta caretta), the olive-ridley turtle (Lepidochelys olivacea) and the leatherback turtle (Dermochelys coriacea) (Anderson, 1898; Ross and Barwani, 1982; Frazier and Salas, 1984). However, only the green and hawksbill turtles are considered common and have been observed nesting and feeding along the Egyptian Red Sea coast (Frazier and Salas, 1984). At present time, these two species are enlisted in the IUCN Red List either as critically endangered, hawksbill turtles (IUCN 2011; Mortimer and Donnelly, 2008), or endangered, green turtles (IUCN 2011; Seminoff, 2004). Furthermore, they are enlisted in Appendix I of the Convention on International trade of Endangered Species (CITES), which forbids their trade in signatory countries (CITES 2011).

Few studies on marine turtles in the Red Sea were reported, although general observations were presented by Ruppell (1835) and Steindachner (1912). Marine turtles of the Red Sea were ignored until late 1970s (Urban, 1970; Moore and Blazarotti, 1977; Waczak, 1979; Hirth and Abdel-Latif, 1980; Sella, 1982). Most of these reports focued on specific sites or small scales. The first review on marine turtles of the Egyptian Red Sea was presented by Frazier and Salas (1984), followed by Frazier et al., (1987).

Green turtle population in the Red Sea is estimated to be around 450 nesting females per year (excluding Eritrea for which data are not available; PERSGA/GEF, 
2004). However, most of the marine turtle population estimates available in the literature are based on scattered surveys and interviews with fishermen. Frazier and Salas (1984) reported less than 100 nests for the green turtle along the entire Egyptian coast. More recently, Hanafy \& Sallam (2003) addressed two major nesting areas for green turtles (Zabargad Island and Wadi El Gimal beach areas) and two valuable offshore areas for the hawkspill (Giftun and Shaker Islands). They also reported scattered nesting events along the coast but at very low-density. More recent estimates consider the green turtle nesting population as being around 1,500 females per year (PERSGA/GEF, 2004). Green turtles are known to nest from August to December in Saudi Arabia (Al Merghani et. al., 2000), while along the Egyptian coast green turtles nests have been found from June to August with a peak in July (Hanafy \& Sallam, 2003).

Hawksbill turtle population in the Red Sea is estimated to be around 450-650 females per year (excluding Eritrea, for which no quantitative data are available; Mortimer and Donnelly, 2008). The population trend is not known, however it is believed that the actual population is smaller than what it used to be mainly due to direct intake for shell trade (Parsons, 1972; Groombridge and Luxmoore, 1989), coastal development and habitat destruction (Miller, 1989) and oil pollution (Frazier and Salas, 1984). The most recent estimate reported a nesting population of 50-100 females per year along the Egyptian Red Sea coast (Mortimer and Donnelly, 2008). This represent age is a negative trend if compared with previous estimate of 200-500 females per year reported by Frazier and Salas (1984) and 200 females per year reported in 2004 (PERSGA/GEF). Main nesting sites for hawksbill turtles are located on the off-shore Shedwan Island and near-shore Giftun Islands groups (Hanafy \& Sallam, 2003). Frazier et al. (1987) reported that hawksbill nests from April to July in Egypt, however according to more recent surveys the nesting season is believed to start in May and finish in July, with a peak in June (Hanafy \& Sallam, 2003).

Currently nesting sites along the Egyptian Red sea coast are submitted to an increasing pressure coming from unsustainable coastal development (Frazier and Salas, 1984; Hanafy \& Sallam, 2003; PERSGA/GEF, 2004). The increasing artificial lightening, habitat degradation due to irrational land use, the growing number of tourists and vessels using the same areas as adults and large juvenile marine turtles, are all well identified threats to nesting turtles (Hanafy \& Sallam, 2003; PERSGA/GEF; 2004; Mortimer and Donnelly, 2008); however no information is available at present on their impact on nesting populations.

This is the first long-term study of nesting activity along the Egyptian Red Sea coast. Therefore, this work aims to quantify trends in nesting activity and identifying highly valuable beaches to be submitted to special management regulations where regular monitoring should be carried out.

\section{MATERIALS AND METHODS}

\section{Identification of nesting sites}

Between 2001 and 2008, 38 beaches along the coast of the Red Sea Governorate starting from Ras Gamsha in the north (60 km north of Hurghada) to Shalateen village in the south (approximately $800 \mathrm{~km}$ of coastline, including 15 islands) were surveyed during the period from 2001 to 2008 (Table 1). The beaches were divided into three regions according to their geographic distribution (northern, central, and southern region, Fig. 1). Beaches were classified into suitable and non- 
suitable for turtle nesting based on the beach profile, sand grains and vegetation (Hirth, 1971; Balazs, 1978; Carr et al., 1982; Corliss et al., 1989; Márquez, 1990).
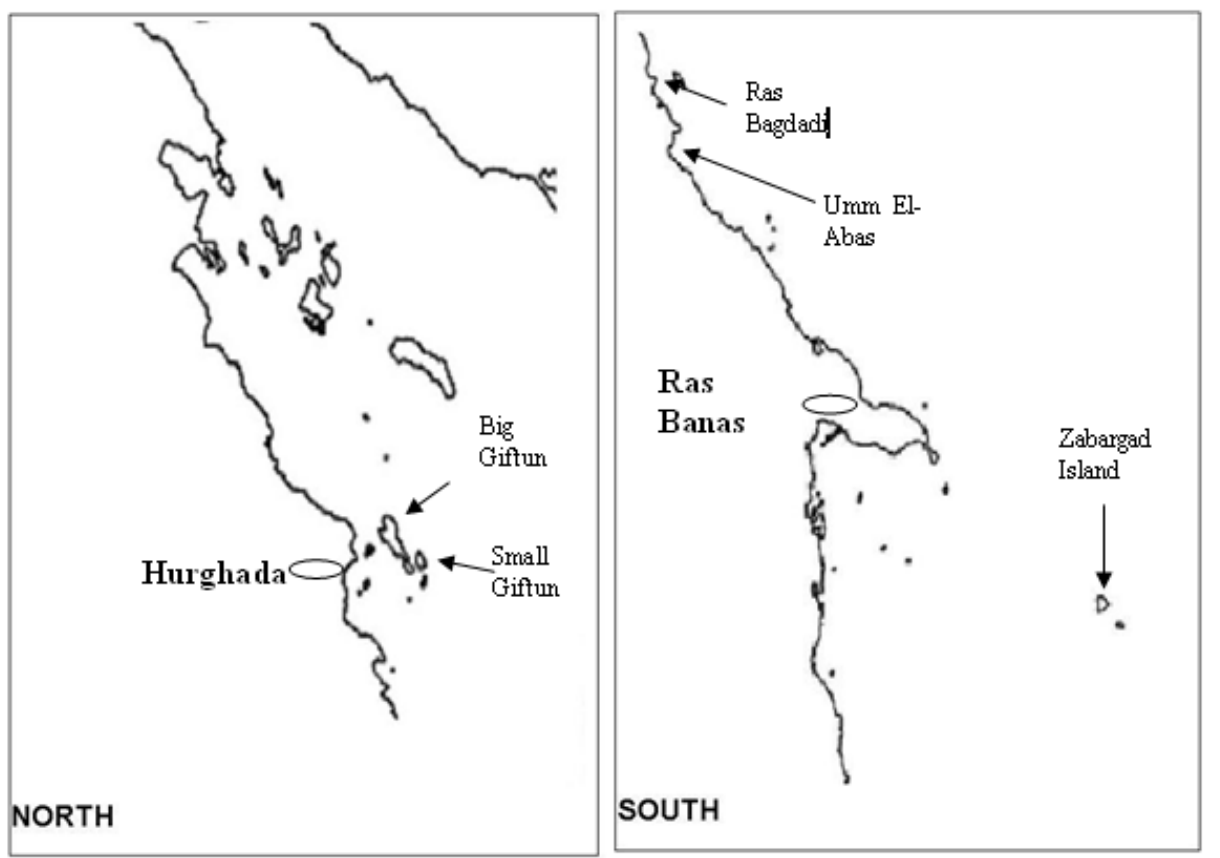

Fig. 1: The five monitored nesting sites in the north for Hawksbill and in the South for green turtles.

The actual nesting beaches were also classified into two categories, i.e. valuable (less than 3 nesting activities, crawls and/or nests) or highly valuable (more than 3 nesting activities). Between 2001 and 2008, the highly valuable sites were re-surveyed on annual basis and nesting activities further were recorded and analyzed.

\section{Nesting activity}

For 3-10 consecutive days between May and September each year (2001-2008), the highest valuable nesting beaches were surveyed during the nesting season (MayJuly for hawksbill and July -September for green turtles), namely Big and Small Giftun Islands for hawksbill, and Zabargad island, Ras Bagdadi and Um Al-Abas for green turtles.

At each beach, data on track width, number of nests and nest diameters were collected. Identification of nesting turtle species was carried out using the shape of the track (asymmetric for hawksbill and symmetric for green turtles; Pritchard and Mortimer, 1999). Turtle tracks were classified into true or false crawls (Schroeder and Murphy, 1999). Nesting success was estimated as the number of true crawls/total no of crawls in each beach. A numbers of 10 and 12 newly nested pits of hawksbill and green turtles (less than 12 hrs after egg lying), respectively, were excavated carefully to determine clutch size (number of egg/clutch), egg diameter (mean of the small and large diameters) and egg weight. In addition the hatchling SCL, SCW and weight were measured from 4 and 3 nests of hawkspill and green turtles, respectively.

Hatching percentages were measured from 8 and 11 nests of green and hawksbill turtles, on Zabargad and Big Giftun Islands, respectively. After hatching, the nests were excavated and the numbers of hatched eggs were counted based on the number of hatched egg shells and the number of un-hatched eggs. The hatching percentages were calculated as a number of hatched eggs to the total number of laid eggs per nest. 


\section{RESULTS}

\section{Nesting beaches and seaso}

Out of the 38 surveyed breaches, 32 beaches were found suitable for marine turtle nesting, $25 \%$ in the northern region $(n=8), 21.9 \%$ in the middle region $(n=7)$ and $53.1 \%$ in the southern region $(n=17)$ (Table 1). Although only 32 beaches were considered suitable for nesting, tracks/nesting activities were recorded on 21 beaches ( $86.5 \%$ of the total), $33.3 \%$ in the northern region $(n=7), 9.5 \%$ in the middle region $(n=2)$ and $57.2 \%$ in the southern region $(n=12)$ (Table 1). Thirteen sites were considered highly valuable for their densities of nesting tracks: two in the northern region and eleven in the southern region (Table 1). In general, hawksbill turtles seemed to use the northern area while the green turtles seemed to use the beaches on the southern region.

Table 1: General inventory of beaches conducted during September-October 2001. The latitude and longitude data refer to the beach middle point. The species refers to the predominant one on the beach $(\mathrm{EI}=$ Eretmochelys imbricate, $\mathrm{CM}=$ Chelonia mydas; Suitability for nesting: - = not suitable, $+=$ suitable; Nesting activity: $-=$ absent,$+=$ low activity, less than 3 crawls, $++=$ high activity, more than 3 crawls).

\begin{tabular}{|c|c|c|c|c|c|c|c|}
\hline $\mathrm{No}$ & Region & Site name & Latitude & Longitude & $\begin{array}{l}\text { Suitability } \\
\text { for nesting }\end{array}$ & $\begin{array}{l}\text { Nesting } \\
\text { activity }\end{array}$ & $\begin{array}{l}\text { Turtle } \\
\text { species }\end{array}$ \\
\hline 1 & North & Al Ashrafy & 27.77544 & 33.69903 & - & - & \\
\hline 2 & North & Umm Al-Karsh & 27.74967 & 33.69569 & + & + & EI \\
\hline 3 & North & Dahart Geisum & 27.72003 & 33.71444 & + & - & \\
\hline 4 & North & Seiul Soghra & 27.70406 & 33.69008 & - & - & \\
\hline 5 & North & Gobal Soghra & 27.67508 & 33.79872 & + & + & EI \\
\hline 6 & North & Gobal Kobra & 27.65406 & 33.78572 & + & + & EI \\
\hline 7 & North & Seiul Kobra & 27.56042 & 33.87608 & + & + & EI \\
\hline 8 & North & Tawila Island & & & - & - & \\
\hline 9 & North & Shedwan Island & 27.53589 & 33.94483 & + & ++ & EI \\
\hline 10 & North & Ras Al Gemsha & 27.65514 & 33.56733 & - & - & \\
\hline 11 & North & $\mathrm{Al}$ Esh & 27.15153 & 33.60158 & - & - & \\
\hline 12 & North & Big Geftun.Island & 27.25975 & 33.95281 & + & ++ & EI \\
\hline 13 & North & Small Giftun Island & 27.21550 & 33.98989 & + & ++ & EI \\
\hline 14 & Middle & North Mangroves & 26.40039 & 34.11253 & + & - & \\
\hline 15 & Middle & North Al-Hamraween & 26.27706 & 34.18822 & + & - & \\
\hline 16 & Middle & South Al-Hamraween & 26.25003 & 34.20031 & + & - & \\
\hline 17 & Middle & Abu Kharouf & 25.82081 & 34.46708 & + & + & $\mathrm{CM}$ \\
\hline 18 & Middle & Marsa Trombi & 25.63264 & 34.58578 & + & - & \\
\hline 19 & Middle & AI-Hommra & 25.57864 & 34.63331 & + & - & \\
\hline 20 & Middle & AI-Malkayia & 25.33356 & 34.80944 & + & + & $\mathrm{CM}$ \\
\hline 21 & Middle & Marsa Agalaa & 25.17408 & 34.84075 & + & - & \\
\hline 22 & South & Wadi El-Gemal Island & 24.66892 & 35.15281 & + & + & $\mathrm{EI} / \mathrm{CM}$ \\
\hline 23 & South & Wadi El-Gemal & 24.66800 & 35.09414 & + & ++ & $\mathrm{EI} / \mathrm{CM}$ \\
\hline 24 & South & Ras Bagdadi North & 24.66622 & 35.10153 & + & ++ & $\mathrm{CM}$ \\
\hline 25 & South & Ras Bagdadi South & 24.66319 & 35.10844 & + & ++ & $\mathrm{CM}$ \\
\hline 26 & South & Ras Hankorab & 24.62414 & 35.10131 & + & ++ & $\mathrm{EI} / \mathrm{CM}$ \\
\hline 27 & South & Umm El-Abas & 24.52597 & 35.13717 & + & ++ & $\mathrm{EI} / \mathrm{CM}$ \\
\hline 28 & South & Ras Banas (Hertawy) & 23.88461 & 35.78564 & + & ++ & $\mathrm{CM}$ \\
\hline 29 & South & Al-Manazek & 23.85711 & 35.48675 & + & - & \\
\hline 30 & South & Sernaka Island & 23.83600 & 35.80281 & + & ++ & $\mathrm{CM}$ \\
\hline 31 & South & Abu Khadaa & 23.75431 & 35.48492 & - & - & \\
\hline 32 & South & Marsa Abu Mad & 23.63200 & 35.50828 & + & - & \\
\hline 33 & South & Zabargad island & 23.83475 & 35.80281 & + & ++ & $\mathrm{CM}$ \\
\hline 34 & South & Marsa Al-Hommaera & 23.45108 & 35.50089 & + & - & \\
\hline 35 & South & Shalateen & 23.14642 & 35.61900 & + & - & \\
\hline 36 & South & Mirear Island & & & + & ++ & $\mathrm{CM}$ \\
\hline 37 & South & Syial Island & & & + & ++ & $\mathrm{CM}$ \\
\hline 38 & South & Rawabeel Island & & & + & ++ & $\mathrm{CM}$ \\
\hline
\end{tabular}

All valuable nesting beaches for hawksbill turtles were found on the northern islands of the Egyptian Red Sea, with two sites of greatest value Big and Small Giftun islands, although other northern island especially Shedwan and Teran islands expect to be more valuable. On the other hand, green turtles were nesting more commonly on 
the southern inshore beaches (i.e. Ras Bagdadi, Umm El-Abas and Ras Banas) and on the offshore beaches of four islands (i.e. Sarenka, Zabargad, Syial and Rawabiel islands, Table 1).

The nesting season of the green turtles on the Egyptian beaches of the Red Sea is extended from June to August with a peak in July, while for the hawksbill it is extended from May to July with a peak in June.

\section{Nesting density and success}

Nesting density and success were monitored annually between 2001 and 2008, on the following beaches: Big and Small Giftun Islands for hawkspill and the offshore Zabargad Island and the inshore beaches of Ras Bagdadi and Umm El-Abas, for the green turtles. Nesting success was estimated as a number of tracks/crawls and true nests. The success varied between species per year and nesting sites. For hawksbill turtle, the number of tracks and true nests recorded per year ranged between 21 and 159, and between 6 and 38 at Big Giftun Island, compared with 4 and 59, and 3 and 14, at the Small Giftun Island, respectively (Table 2). In addition, the estimated annual nesting success, as a percentage of nest count/ track count averaged 24.0 and $27.6 \%$, at the Big and Small Giftun, respectively.

Nesting success and density for green turtles were estimated at three surveyed sites. In general, Zabargad Island is found to be the most valuable nesting ground for green turtle on the Egyptian coast of the red Sea. The count of tracks recorded on the beaches of the offshore Zabargad Island varied between 730 in 2001 and 3083 tracks in 2006, with a true nest ranged between a lowest count of 438 in 2001 and a highest count of 1527 nests in 2008. The percentage of the nesting success ranged between 33.5 in 2007 and $64.5 \%$ in 2004 (Table 2). The annual overall means of tracks, true nest counts and percentage of nesting success estimated 1901, 920 and 52.2\%, respectively (Table 2). The two inshore beaches of Ras Bagdadi and Umm Al-Abas nesting densities of green turtles were found to be declined with years. At Ras Begdadi the counts of tracks and true nests decreased from 48 and 29 in 2001 to only 6 and 2 in 2006, and with annual means of 29.4 and 16.2, respectively (Table 2). Similarly at Umm Abas, the counts decreased from 65 and 33 in 2001 to only 3 and 1 in 2007, and with annual means of 29.4 and 16.2, respectively (Table 2).

Table 2: Total number of crawls (TC), true nests (TN) and estimated nesting success (NS\%= TN/TC x 100), estimated annually at the nesting beaches of hawksbill turtles ( Big and Small Giftun) and the nesting beaches of green turtles (Ras Bagdadi, Umm El-Abas and Zabargad Island).

\begin{tabular}{|c|c|c|c|c|c|c|c|c|c|c|}
\hline Site name & Parameters & 2001 & 2002 & 2003 & 2004 & 2005 & 2006 & 2007 & 2008 & Annual means \\
\hline \multirow[t]{3}{*}{ Big Giftun } & TC & 21 & $\mathrm{n} / \mathrm{a}$ & 48 & 61 & 119 & 159 & 155 & $\mathrm{n} / \mathrm{a}$ & 93.8 \\
\hline & $\mathrm{TN}$ & 6 & & 12 & 19 & 18 & 38 & 31 & & 20.7 \\
\hline & NS (\%) & 28.6 & & 25 & 31.1 & 15.1 & 23.9 & 20 & & 22.0 \\
\hline \multirow[t]{3}{*}{ Small Giftun } & $\mathrm{TC}$ & 4 & $\mathrm{n} / \mathrm{a}$ & 4 & 35 & 59 & 32 & $\mathrm{n} / \mathrm{a}$ & $\mathrm{n} / \mathrm{a}$ & 26.8 \\
\hline & TN & 4 & & 3 & 6 & 14 & 14 & & & 8.2 \\
\hline & NS (\%) & 100 & & 75 & 17.1 & 23.7 & 43.7 & & & 30.6 \\
\hline \multirow[t]{3}{*}{ Total } & $\mathrm{TC}$ & 25 & $\mathrm{n} / \mathrm{a}$ & 52 & 96 & 178 & 191 & 155 & $\mathrm{n} / \mathrm{a}$ & 93.8 \\
\hline & $\mathrm{TN}$ & 10 & & 15 & 25 & 32 & 52 & 31 & & 20.7 \\
\hline & NS (\%) & 40.0 & & 28.8 & 26.0 & 18.0 & 27.2 & 20.0 & & 22.1 \\
\hline \multirow[t]{3}{*}{ Ras Bagdadi } & $\mathrm{TC}$ & 48 & 39 & 48 & 14 & 24 & 6 & $\mathrm{n} / \mathrm{a}$ & $\mathrm{n} / \mathrm{a}$ & 29.8 \\
\hline & $\mathrm{TN}$ & 29 & 26 & 37 & 11 & 11 & 2 & & & 19.3 \\
\hline & NS (\%) & 60.4 & 72.2 & 77.1 & 78.8 & 45.8 & 33.3 & & & 64.8 \\
\hline \multirow[t]{3}{*}{ Uum Al-abass } & TC & 65 & 56 & 45 & 16 & 11 & 10 & 3 & $\mathrm{n} / \mathrm{a}$ & 29.4 \\
\hline & $\mathrm{TN}$ & 33 & 30 & 28 & 10 & 5 & 7 & 1 & & 16.3 \\
\hline & NS (\%) & 50.8 & 53.6 & 62.2 & 62.5 & 45.4 & 70 & 33.3 & & 55.4 \\
\hline \multirow[t]{3}{*}{ Zabargad } & $\mathrm{TC}$ & 730 & $\mathrm{n} / \mathrm{a}$ & 1257 & 1045 & 1465 & 3083 & 3324 & 2409 & 1901.8 \\
\hline & $\mathrm{TN}$ & 438 & & 512 & 675 & 718 & 1456 & 1114 & 1527 & 88.6 \\
\hline & NS (\%) & 60 & & 40.7 & 64.5 & 49.0 & 47.2 & 33.5 & 63.4 & 46.1 \\
\hline \multirow[t]{3}{*}{ Total } & $\mathrm{TC}$ & 843 & & 1350 & 1075 & 1500 & 3099 & 3327 & 2409 & 1943.3 \\
\hline & TN & 500 & & 577 & 696 & 734 & 1465 & 1115 & 1527 & 944.9 \\
\hline & NS (\%) & 59.3 & & 47.7 & 64.7 & 48.9 & 47.3 & 33.5 & 63.4 & 48.6 \\
\hline
\end{tabular}




\section{Hatching percentage}

Hatching percentages were measured from 8 and 11 nests of green and hawksbill turtles on Big Giftun and Zabargad Islands, respectively. Despite the nests laid in the intertidal area where hatching was failed completely in the nests of both species, the ranges of hatching percentages in nests laid 5 to $15 \mathrm{~m}$ above the high water mark estimated 71.1-96 and 53.4-96.3\%, with overall means of $87.2 \pm 7.45$ and $66.5 \pm 13.13 \%$ to the total count of eggs for green and hawksbill turtles, respectively (Table 3).

Table 3: Measurements of female size (CCL and CCW), track width, nest diameter, egg weight, egg diameter, hatchling weight and size (SCL and SCW), estimated at the two nesting sites of Zabargad Island for green turtles and Big Giftun for the hawksbill turtles.

\begin{tabular}{|c|c|c|c|c|c|c|}
\hline \multirow[t]{2}{*}{ Parameters } & \multicolumn{3}{|c|}{ Green turtles } & \multicolumn{3}{|c|}{ Hawksbill } \\
\hline & $\mathrm{n}$ & range & mean \pm SD & $\mathrm{n}$ & range & mean \pm SD \\
\hline $\begin{array}{l}\text { Female CCL }(\mathrm{cm}) \\
\text { Female CCW }(\mathrm{cm})\end{array}$ & $\begin{array}{l}76 \\
76\end{array}$ & $\begin{array}{l}92-120 \\
84-102\end{array}$ & $\begin{array}{l}104 \pm 5.28 \\
94.3 \pm 3.0\end{array}$ & N.S & N.S & N.S \\
\hline $\begin{array}{l}\text { Track width }(\mathrm{cm}) \\
\text { Nest diameter }(\mathrm{cm})\end{array}$ & $\begin{array}{l}220 \\
186 \\
\end{array}$ & $\begin{array}{l}75-130 \\
135-385\end{array}$ & $\begin{array}{l}99.5 \pm 10.7 \\
217.7 \pm 45.5\end{array}$ & $\begin{array}{l}65 \\
36 \\
\end{array}$ & $\begin{array}{l}50-100 \\
101-290 \\
\end{array}$ & $\begin{array}{l}70.4 \pm 5.5 \\
181 \pm 28.7\end{array}$ \\
\hline Clutch size & $\begin{array}{l}12 \\
8 \mathrm{RB}\end{array}$ & $\begin{array}{l}66-121 \\
31-47 \\
\end{array}$ & $\begin{array}{l}100.1 \pm 21.7 \\
41.4 \pm 5.8\end{array}$ & 13 & $30-95$ & $74 \pm 17.73$ \\
\hline Egg weight (gm) & $249(12)^{*}$ & $37-76$ & $52.9 \pm 7.95$ & $77(10)^{*}$ & $22-42$ & $31.0 \pm 5.02$ \\
\hline Egg diameter $(\mathrm{mm})$ & $249(12)^{*}$ & $37.5-51.5$ & $44.2 \pm 2.7$ & $77(10)^{*}$ & $29-41$ & $36.1 \pm 2.87$ \\
\hline Hatching percentage $(\%)$ & 8 & $71.1-96.0$ & $87.2 \pm 7.45$ & 11 & $53.4-96.3$ & $66.5 \pm 13.13$ \\
\hline $\begin{array}{l}\text { H SCL }(\mathrm{cm}) \\
\text { H SCW }(\mathrm{cm}) \\
\text { H weight }(\mathrm{gm})\end{array}$ & $\begin{array}{l}12(3)^{*} \\
12(3)^{*} \\
12(3)^{*}\end{array}$ & $\begin{array}{l}3.5-5.4 \\
3.0-4.7 \\
16-27\end{array}$ & $\begin{array}{l}4.34 \pm 0.45 \\
3.51 \pm 0.47 \\
22.5 \pm 3.45\end{array}$ & $\begin{array}{l}21(4) * \\
21(4) * \\
21(4) *\end{array}$ & $\begin{array}{l}3.4-4.6 \\
2.5-3.2 \\
14.3-16.2\end{array}$ & $\begin{array}{l}4.16 \pm 0.27 \\
2.85 \pm 0.25 \\
15.14 \pm 0.57\end{array}$ \\
\hline
\end{tabular}

CCL, curved carapace length; CCW, curved carapace width; HSCL, hatchling straight carapace length; HSCW, hatchling straight carapace width; RB, Ras Bagdadi nesting beach; ( )*, number of nests.

\section{Size parameters of female, track, nest, clutch, eggs and hatchlings}

Measurements of female size (CCL and CCW), track width, nest diameter, egg weight and diameter, and hatchling size (SCL and SCW) of the two turtle species are given in Table (3). Green turtle female CCL and CCW ranged between 92-120 and 84-102 $\mathrm{cm}$, respectively, measured from Zabargad Island population $(\mathrm{n}=76$; means $=$ $104 \pm 5.28$ and $94.3 \pm 3.00 \mathrm{~cm}$, respectively). The track widths and nest diameters averaged $99.5 \pm 10.7$ and $70.4 \pm 5.5 \mathrm{~cm}$, and $217.7 \pm 45.5$ and $181 \pm 28.7 \mathrm{~cm}$ for green and hawksbill turtles, respectively (Table 3 ).

Egg weight and diameter were measured in 249 eggs of green turtles and 77 eggs of hawksbill turtle. Egg weight of green turtle ranged from 37 to $76 \mathrm{gm}$, with an overall mean of $52.9 \pm 7.95 \mathrm{gm}$, while it ranged from 22 to $42 \mathrm{gm}$ for hawksbill (mean= $31.0 \pm 5.02 \mathrm{gm}$ ). Egg diameter in green and hawksbill turtles ranged between 37.5$51.5 \mathrm{~mm}$ and $29-41 \mathrm{~mm}$, with overall means of $44.2 \pm 2.7$ and $36.1 \pm 2.87 \mathrm{~mm}$, respectively (Table 3 ).

Clutch size, as a number of eggs per clutch, was determined for green turtles from 12 nests at Zabargad Island and 8 nests at Ras Bagdadi nesting beach. As well as the clutch size of hawksbill was measured from 13 nests at the nesting beach of Big Giftun Island. Cluch sizes were found to be varied significantly between both species as well as between green turtle nests at Zabargad Island and Ras Bagdadi nesting beach $(\mathrm{p}<0.001)$. Clutch sizes of green turtle ranged between 66 and 121 at the zabargad Island and between 31-47 eggs only at the Ras Bagdadi beach, with overall means of $100.1 \pm 21.7$ and $41.4 \pm 5.8$ eggs/clutch, respectively. In comparison, lower range of $30-95$ eggs/clutch, with an overall mean of $74 \pm 17.73$ eggs/clutch was estimated for hawksbill turtle (Table 3). 
Hatchling SCL, SCW and weight were measured in 12 hatchlings of green turtles and 21 hatchlings of hawkspill turtles. For green turtle hatchlings, the estimated ranges were being $3.5-5.4 \mathrm{~cm}, 3.0-4.7 \mathrm{~cm}$ and $16-27 \mathrm{gm}$, with overall means of $4.34 \pm 0.43 \mathrm{~cm}, 3.51 \pm 0.47 \mathrm{~cm}$ and $22.5 \pm 3.45 \mathrm{gm}$, respectively. Smaller ranges were estimated for the hatchlings of hawksbill, being $3.4-4.6 \mathrm{~cm}, 2.5-3.2 \mathrm{~cm}$ and $14.3-$ $16.2 \mathrm{gm}$, with overall means of $4.16 \pm 0.27 \mathrm{~cm}, 2.85 \pm 0.25 \mathrm{~cm}$ and $15.14 \pm 0.57 \mathrm{gm}$, respectively (Table 3).

\section{DISCUSSION}

Although the factors driving the selection of a nest site on a specific beach are not well understood for marine turtles (Limpus et al. 1983; Hays et al. 1995; Mortimer 1990; Wood \& Bjorndal, 2000; Miller et al. 2003; Kamel \& Mrosovsky, 2005), several factors may be influential in the choice of an optimal nesting site (e.g. low salinity, high humidity, infrequently inundated, well ventilated, with nearshore oceanography conducive to dispersal of hatchlings into oceanic currents; Miller 1997 and Foley et al. 2006). There should be sufficient space above the high tide line for nesting to take place and, for some species and/or locations; there should be adequate beach vegetation for clutch shading (Naro-Maciel et al., 1999, van de Merwe et al. 2005, Kamel \& Mrosovsky, 2006). However, persistence of a nesting site depends on the successful production of hatchlings that re-nest later at the same site, so the success of a particular nesting beach is only revealed after a period of many years.

In case of the Egyptian beaches of the Red Sea, the rapid and intensive tourism development along the shoreline, beaches over-use, beach reclamation and lighting are threatening nesting of marine turtles on the inshore beaches. Fortunately, the most valuable nesting sites for both species of hawksbill and green turtles are laying within the boundaries of the Red Sea Protected Areas and offshore, non-permits to visitors except the Big Giftun Island. However, due to lack of baseline data on turtle nesting, it is unrealistic to quantify the impact of tourism development on the inshore nesting beaches.

Counting the number of clutches laid per season is the most common technique to assess population size and trends (Schroeder and Murphy, 1999). However, it is known that accurate estimates could be difficult when the nesting sites are scattered on a wide area or located in inaccessible sites (Godley et al., 2001; SWOT 2010). The great fluctuations in the number of annual arrivals of nesting turtles are well known pattern and documented in different species worldwide, i.e. loggerhead (Hughes, 1974: Davis \& Whiting, 1977; Richardson \& Richardson, 1978); green turtles (Limpus, 1982; Al-Gheilani, 1996). At the present work, the densities of nesting (e.g. numbers of total tracks/crawls and true crawls/nests) varied tremendously between sites and years. Both sites of Zabargad and Giftun Islands are considered the most valuable surveyed nesting beaches of the Egyptian coast of the Red Sea for green and hawksbill turtles, respectively. In addition to the natural pattern, the tremendous annual fluctuations of nesting densities at all surveyed beaches are also attributed to the variation in the survey date and length, i.e. surveying a certain beach at the beginning of the nesting season for few days is expected to count lower number of nests than surveying same beach at the middle or end of the nesting season. The occurrence of extremely higher number of false nests comparing with the number of true nests on the Big Giftun Island could be related to some sort of human impact. Big Giftun Island is the only island permits to visitors to get access. The annual number of 
visitor increased from 30,000 - 40,000 visitors between 2001 and 2004, then sharply to over than 100,000 a year starting from 2005 (Red Sea Protectorates Authority).

The recorded decline in nesting densities of green turtles on the inshore beaches of Ras Bagdadi and Umm Al-Abas, in particular, is seemed to be another example of human impact. The two sites lie closely to a traffic highway, especially the beach of Umm Al-Abas site. Although the two sites lie within the boundary of the declared Wadi-Al Gimal National Park (WGNP), both sites are influenced by traffic activities on the highway which cross the beach of Um Al-Abas and pass close to the beach of Ras Bagdadi. With the rapid growing of tourism development along the shore line on the boundary of WGNP, traffic activities are intensified and lighting from cars and resorts became extremely more frequently causing serious impact on these beaches. Light pollution is well documented as a major problem on many sea turtle nesting beaches by, discouraging females from nesting (Witherington, 1992) and altering nesting pattern (Salmon et al., 2000); disturbing hatchling orientation (Witherington and Martin, 2000).

Due to lack of proper surveys as well as lack of long term monitoring for the nesting beaches, there is no clear and accurate estimates for population sizes of green and hawksbill populations in the Egyptian Red Sea. Green turtle nesting female population in the whole Red Sea excluded Eritrea is estimated to be around 450 females (PERSGA/GEF, 2004). Frazier and Salas (1984) reported less than 100 nests for the green turtle along the entire Egyptian coast of the Red Sea. Hanafy and Salam (2003) counted more than 1,500 nests of green turtle at 5 nesting sites of the Egyptian Red Sea. For hawksbill, Mortimer and Donnelly (2008) estimated the number of nesting females in the whole Red Sea to be in a range of 450-650 females per year. In contrast, Frazier et al. (1987) estimated that approximately 500 hawksbill turtles nest mainly on the offshore island from Ras Banas to the island at the mouth of the Gulfs of Suez and Aqaba. Frazier and Salas (1984) and Frazier et al. (1987) considered hawksbill turtles as the most common while green turtles the second most common species in the Egyptian Red Sea, due the scarcity of feeding habitat of the green turtles.

In comparison, the current long term study concluded that the hawksbill turtles, at least as nesting population, are less common rather than green turtles and their nesting beaches are restricted only to the offshore islands at the mouths of the both Gulfs and not far south. The differences in both findings are related mainly to; 1) The former studies were based mainly on interviews with fishermen and divers, where their activities and observations are mainly linked to the coral reefs (hawksbill main habitat) rather than sea grasses (green turtles habitat; 2) The surveys of the former studies were limited in time and access to remote nesting beaches such as Zabargad Island (the most valuable nesting beaches for green turtles).

The nesting beaches are perhaps the only practical place to determine turtle population size in certain area. According to Marquez (1990), the beach arrived green turtle nesting females lay 2.5 clutches per season as well as Carr et al. (1978) stated that the total population of green turtles is three times the number of nested female. Consequently, the count of true nest, although, varied greatly and significantly between years, (Fig. 2) show the annual estimated numbers of nested females and population size of the green turtle population, based on the data collected from the annual surveyed beaches. The estimated number of nested females increased gradually from 200 in 2001 to the highest number of 610.8 females in 2008. Same trend was estimated for population size (total number of green turtles), where they increased from 600 in 2001 to 1832 individuals in 2008. This trend of increasing with 
years is mainly related to the hard accessibility to the nesting beaches of Zabargad Island and, the time and period of survey to the nesting season. With improving the monitoring method, selecting proper time of survey and increasing the number of days available for survey at these beaches seemed to allow counting more and more crawls and true nests with years.

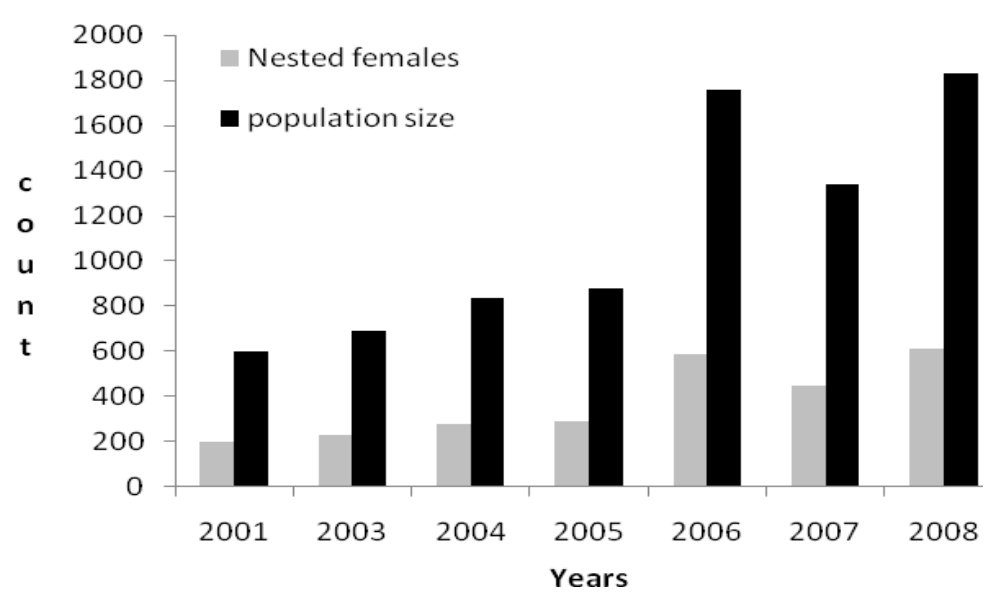

Fig. 2: Estimated numbers of annual arrived nested females and estimated population of green turtles.

Richardson et al. (1999) estimated the mean remigration interval for hawksbill female on West Indies beaches to be 2.69 years and the female laid in average 5 clutches per nesting season. Based on these estimates as well as the number of clutches counted on the beaches of Small and Big Giftun Islands, it may conclude that the population size of the annual arrived nesting female hawksbill on both islands is small and may be represented by few to dozens of individuals. Based on personal observation, I deeply believed that other un-surveyed northern islands (where access to these islands is prohibited), especially Shedwan and Tiran may represent more valuable nesting sites for hawksbill turtles.

The mean size of the arrived nesting green turtle females on Zabargad Island (mean CCL $=104 \pm 5.28$ ) found to be fitted with the recorded CCL range of 95 and $112 \mathrm{~cm}$, from different nesting sites worldwide. Also the mean clutch sizes of green turtles is varied between nesting beaches worldwide and found to be ranged between 88 and 160 eggs/clutch. (Hendrickson, 1958; Carr and Hirth, 1962; Pritchard, 1969; Frazier, 1971; Hirth, 1971; Firdous, 1985; Bjorndal \& Carr, 1989; Gheilani, 1996, Miller, 1997). The estimated clutch size of green turtles on Zabargad nesting beaches fitted with the findings of the former authors (mean=100.1 \pm 12.7 eggs/clutch). In contrast, an extremely lower clutch sizes were recorded in 8 nests from Ras Bagdadi beach (mean $=41.4 \pm 5.5$ eggs/clutch). It is questionable, is the stress of light pollution on females during laying their eggs could reduce the clutch sizes?

In hawksbill turtles, the number of eggs per clutch averaged $74 \pm 17.7$. This figure is extremely under-estimated the figures of 155 and 163.5 eggs/clutch in West Indies and Seychelles, given by Richardson et al (1999) and Diamond (1976), respectively. Similarly, lower hatching percentage of $66,5 \pm 13.13 \%$ was estimated compared with the recorded hatching percentage of $90 \%$ in the hawksbill clutches from Seychelles (Diamond, 1999)

The egg diameter in green turtles estimated from different areas worldwide range between 40 and 55mm (Hendrickson, 1958; Carr and Hirth, 1962; Frazier, 1971; Hirth, 1971; Firdous, 1985; Gheilani, 1996; Miller, 1997). The estimated egg diameter for green turtles in the Egyptian Red Sea found to be within the same range 
(mean=44.2 $\pm 2.7 \mathrm{~mm}$ ). Hatchling weight and size (SCL and SCW) were found to be similar to the means values recorded for hatchlings of green turtles recorded from the nesting beaches Ras Baridi on the Saudi's coast of the Red Sea (Al-Mansi et. al., 2003).

In conclusion, the inshore nesting beaches of the Egyptian Red Sea are impacted by the ongoing intensive coastal development along the shoreline. It is very discouraging to note that some critical habitats are quickly being degraded or placed at risk. Increasingly, the development of tourist resorts of various dimensions, installing tourism beach facilities, coastal roads, and other developments are transforming nesting beaches and increasing the destruction of reef environments that critical to the survival of marine turtles.

Specific mitigation measures must be implemented to conserve these beaches, such as: excluding nesting beaches from the coastal development process, reducing light intensity and beach uses, at least, during the nesting season, raising local community awareness toward conservation of marine turtles and strengthening law enforcement process. Fortunately, all of the valuable offshore nesting beaches are located within declared marine protected areas. This study was created some sort of stability, continuity, and monitoring coverage for almost 8 nesting seasons. It is contributed for future complete baseline for green and hawksbill turtlesbreeding population's trends in the Egyptian Red Sea.

\section{ACKNOWLEDGEMENTS}

I am deeply indebted to all marine biologists, who supported field data gathering and made the present work possible; particularly Salam, A. Sedeak A. Moneer, T. Al-Sayed Y. S., Soliman, S. Nagm, M. El-Shafee A.; Dr. Mancheni, A. and Dr. Ismail, M. I wish express my thanks to the Red Sea Protectorates Authority and Hurghada Preservation and Conservation Association (HEPCA), through which this study was undertaken.

\section{REFERENCES}

Al-Gheilani, H. M. (1996). Environmental and biological Study on the Green Turtles in Ras Al-Had Region in Sultant of Oman. M. Sc. Thesis, Suez Canal University, 165 pp.

Al-Mansi, A. M.; Sambas, A. Z. and Badawi, S. F. (2003). The marine turltes in Saudi arabian Red Sea coast: Their biology and conservation. National Report to PERSGA, 28 pp.

Al-Merghani, M.; Miller, J. D.; Pilcher, N. J.; Al-Mansi, A. (2000). The green and hawksbill turtles in the Kingdom of Saudi Arabia: Synopsis of nesting studies 1986-1997. Fauna of Arabia, 18: 369-384.

Anderson, J. (1898). Zoology of Egypt. London, Bernard Quaritch.

Balazs, G. H. (1978). Terrestrial critical habitat for sea turtles under United States jurisdiction in the Pacific region. An overview of existing knowledge. Elepaio, Journal of the Hawaii Audubon Society, 39:37-41.

Bjorndal, K. A. and Carr, A. F. (1989). Variation in clutch size and egg size in the green turtle nesting population at Tortuguero, Costa Rica. Herpetologica, 45: 181-189.

Carr, A. F and Hirth, H. F. (1962). The ecology and migration of sea turtles. 5. Comparative features of isolated green turtle colonies. American Museum Novitates, 2091: 1-42.

Carr, A.; Meylan, F.; Mortimer, J.; Bjorndal K.; and Carr. T. (1982). Surveys of sea turtles populations and habitats in the Western Atlantic. NOAA Technical Memorandum NMFS-SEFC-91. U.S. Department of Commerce. 82 pp. 
Carr, A. F.; Carr, M. H. and Meylan, A. B. (1978). The ecology and migration of sea turtles. 7. The West Caribbean green turtle colony. Bulletin of the American Museum Of Natural history, 162: 1-46.

CITES (2011). CITES Secretariat Web site. Available at: http://www.cites.org, revised on February 2011.

Corliss, L. A.; Richardson, J. I.; Ryder, C. and Bell. R. (1989). The hawksbill of Jumby Bay, Antigua, West Indies,.33-36 pp. In: S. A. Eckert, K. L. Eckert and T. H. Richardson (Compliers), Proceedings of the Ninth Annual Workshop on Sea Turtle Conservation and Biology. NOAA Technical Memorandum NMFS-SEFC-232. U.S. Department of Commerce.

Davis, G. E. and Whiting, M. C. (1977). Loggerhead sea turtle nesting in Euerglades National Park, Florida, U.S.A. Herpetologica, 33: 18-28.

Diamond, a. W. (1976). Breeding biology and conservation of hawksbill turtles Eretmochelys imbricate L., on Cousin Island, Seychelles. Biol. Conserv., 9: 199-215.

Firdous, F. (1985). Research and conservation of marine turtles along the Karachi coast. Proc. Symp. Endangered Marine Animals and Marine Parks, 1: 285-289.

Foley, A. M., Peck S. A., Harman G. R. (2006). Effects of sand characteristics and inundation on the hatching success of loggerhead sea turtle (Caretta caretta) clutches on lowrelief mangrove islands in southwest Florida. Chelonian Conserv Biol, 5:32-41

Frazier, J. (1971). Observation of sea turtles at Aldabra Atoll. Philosophical transactions of the royal Society of London (B), 260:373-410.

Frazier, J. and Salas, S. (1984). The status of marine turtles in the Egyptian red Sea. Biol. Conserv., 30: 41-67.

Frazier, J.; Bertram, G.C. and Evans, P. G. (1987). Turtles and marine mammals. pp. 288-314. In: Key Environments: Red Sea. (A.J. Edwards and A.M. Head, eds.) Pergamon Press, Oxford.

Frazier, J., Salas, S. 1984. The status of marine turtles in the Egyptian Red Sea. Biol. Conserv., 30: 41-67.

Godley, B.J., Broderick, A.C., Hays, G. C. (2001). Nesting of green turtles (Chelonia mydas) at Ascension Island, South Atlantic. Biol. Conserv., 97: 51-58.

Groombridge, B. and Luxmoore, R. (1989). The green turtle and hawksbill (Reptilia: Cheloniidae): World status, exploitation, and trade. Lausanne, Switzerland: CITES Secretariat, $601 \mathrm{pp}$.

Hanafy, M. H. and Sallam, A. (2003). Status of marine turtles nesting on the Egyptian beaches of the Red Sea. National Report to PERSGA, $45 \mathrm{pp}$.

Hays G. C.; Mackay, A.; Adams, C. R.; Mortimer, J. A.; Speakman, J. R.; and Boerema, M. (1995). Nest-site selection by sea turtles. J. Mar. Biol. Assoc. UK., 75:667-674

Hendrickson, J. R. (1958). The green turtle, Chelonia mydas, in Malysia and Sarawak. Proceeding of the zoological Society of London, 130: 455-535.

Hirth, H. F. (1971). Synopsis of Biological Data on the Green Turtle, Chelonia mydas (Linnaeus 1758). FAO Fisheries Synopsis, FIRM/S., 85:1-75.

IUCN (2011). IUCN Red List of Threatened Species. Available at: http://www.iucnredlist.org/, revised on February 2011.

Hughes, G. R. (1974). The sea turtles of Southeast Africa. 1. Status, morphology and distribution. Oceanographic Research Institute Investigational Report, Durban, 35: 1144.

Kamel, S. J.; Mrosovsky, N. (2005). Repeatability of nesting preferences in the hawksbill sea turtle, Eretmochelys imbricata, and their fitness consequences. Anim Behav., 70:819828.

Kamel, S. J., Mrosovsky, N. (2006). Deforestation: Risk of sex ratio distortion in hawksbill sea turtles. Ecol. Appl., 16: 923-931

Limpus, C. J. (1982). The Status of Australian Sea Turtles Population. Bjorndal, K. A. Biology and Conservation of sea Turtles. Smithsonian Institution Press, Washington, D. C. 297-303 pp. 
Limpus, C. J; Miller, J. D; Baker, V. and McLachlan, E. (1983). The hawksbill turtle, Eretmochelys imbricata (L.), in north-eastern Australia: the Campbell Island rookery. Aust. Wildl. Res., 10:185-197.

Márquez, R. (1990). FAO Species Catalogue Vol. 11: Sea turtles of the world. An annotated and illustrated catalogue of sea turtle species known to data. FAO Fisheries Synopsis, 11:1-81.

Miller, J. D. (1989). Marine Turtles, Volume 1: An assessment of the conservation status of Marine Turtles in the Kingdom of Saudi Arabia. MEPA, Jeddah, Saudi Arabia. Report No. 9, 289 pp.

Miller, J. D. (1997). Reproduction in sea turtles. In: Lutz PL, Musick JA (eds.) The biology of sea turtles, Vol 1. CRC Press, Boca Raton, FL, 51-81pp.

Miller, J. D. (2004). Report on marine turtles of Wadi El Gemal-Hamata Park, Southern Red Sea Coast, Egypt. Report to the Red Sea Protectorate Authority, Hurghada, Egypt.

Miller, J.D., Limpus, C. J., Godfrey, M. H. (2003). Nest site selection, oviposition, eggs, development, hatching, and emergence of loggerhead turtles. In: Bolten AB, Witherington BE (eds) Loggerhead sea turtles. Smithsonian Books, Washington, DC, $125-143 \mathrm{pp}$.

Mortimer, J. (1982). Feeding ecology of sea turtles. In: Bjorndal KA (ed) Biology and conservation of sea turtles. Smithsonian Institution Press, Washington, D.C., 103-109 $\mathrm{pp}$.

Mortimer, J.A., Donnelly, M. (2008). In: IUCN 2010. IUCN Red List of Threatened Species. Version 2010.4. <www.iucnredlist.org>. Downloaded on 06 June 2011.

Naro-Maciel, E., Mrosovsky, N., Marcovaldi, M. A. (1999). Thermal profiles of sea turtle hatcheries and nesting areas at Praia do Forte, Brazil. Chelonian Conserv. Biol., 3: 407-413

Parsons, J. J. (1972). The hawksbill turtle and the tortoise shell trade. In: Études de géographie tropicale offertes a Pierre Gourou. Paris: Mouton., 45-60 pp.

PERSGA/GEF. (2004). Regional Action Plan for the Conservation of Marine Turtles and their Habitats in the Red Sea and Gulf of Aden. PERSGA, Jeddah.

Pritchard, P.C.H. (1969). Sea turtles of the Guianas. Bulletin of the Florida state Museum, 13: $85-140$.

Pritchard, P. C.; Mortimer, J. A. (1999). Taxonomy, external morphology and species identification. In Eckert, K. L., K. A. Bjorndal, F. A. Abreu-Grobois, and M. Donnelly, eds. Research and Management Techniques for the Conservation of Sea Turtles. IUCN/SSC Marine Turtle Specialist Group Publication No. 4

Richardson, J. I. and Richardson, T. H. (1978). Population estimates for nesting female loggerhead sea turtles (Caretta caretta) in the St. Andrew sound area of Southeast Gorgia, U.S.A. Florida Departement of National Resources Marine Research laboratory, 33: 34-38.

Richardson, J. I.; Bell, R. and Richardson, T. H. (1999). Population ecology and demographic drawn from an 11-year study of nesting hawksbill turtles, Eretmochelys imbricate, at junby Bay, Long Island, Antigua, wast indies. Chelonian Conservation and biology, 3(2): 244-250.

Ross, J. P.; Barwani, M. A. (1982). Review of sea turtles in the Arabian Area. In: Biology and Conservation of Sea Turtles (K. A. Bjorndal, ed.): 373-382. Smithsonian Institution Press, Washington, D. C.

Schroeder, B. and Murphy, S. (1999). Population surveys (ground and aerial) on nesting beaches. In Eckert, K. L., K. A. Bjorndal, F. A. Abreu-Grobois, and M. Donnelly, eds. Research and Management Techniques for the Conservation of Sea Turtles. IUCN/SSC Marine Turtle Specialist Group Publication, No. 4.

Seminoff, J. A. (2004). MSTG global assessment of green turtles (Chelonia mydas) for the IUCN Red List. IUCN Species Survival Commission, April 2004. Available at: http://www.iucn-mtsg.org/red list/cm/MTSG_Chelonia mydas Assessment April2004. pdf. 
SWOT Scientific Advisory Board (2011). The State of the World's Sea Turtles (SWOT) Minimum Data Standards for Nesting Beach Monitoring. Technical Report, 24 pp.

Van de Merwe, J.; Ibrahim, K. and Whittier, J. (2005) Effects of hatchery shading and nest depth on the development and quality of Chelonia mydas hatchlings: Implications for hatchery management in Peninsular, Malaysia. Aust. J. Zool., 53:205-211

Witherington, B. E. (1992). Behavioral responses of nesting sea turtles to artificial lighting. Herpetologica, 48:31-39.

Witherington, B. E. and Martin, R. E. (2000). Understanding, Assessing, and Resolving Light-Pollution Problems on Sea Turtle Nesting Beaches (Revised Edition) Florida Fish and Wildlife Conservation Commission, FMRI Technical Report TR-2. Tallahassee, Florida. 73 pp.

Wood, D. W.; Bjorndal, K. A. (2000). Relation of temperature, moisture, salinity, and slope to nest site selection in loggerhead sea turtles. Copeia, 2000:119

\section{ARABIC SUMMARY}

$$
\begin{aligned}
& \text { تعشيش السلاحف البحرية على الثواطئ المصرية للبحر الاحمر }
\end{aligned}
$$

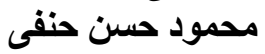

$$
\begin{aligned}
& \text { قسم علوم البحار ـ كلية العلوم-جامعة قناة السويس- الاسماعيلية- جمهورية مصر العربيه }
\end{aligned}
$$

تم دراسة أنشطة التعشيش لنوعين من السلاحف البحرية على الثواطئ المصرية للبحر البحر الاحمر وهما

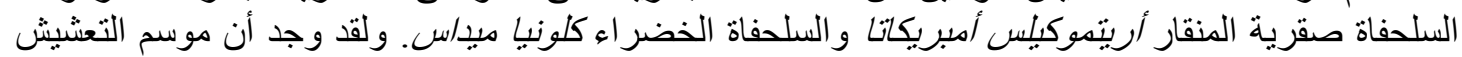

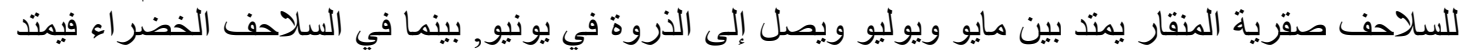

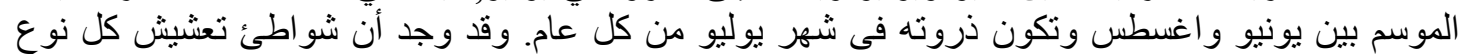
منفصلة عن النوع الاخر.

في هذه الدراسة تم مسح عدد 38 شاطئ بطول ساحل البحر الأحمر الاحمر المصرى وتقسيمها طبقا لكثافة

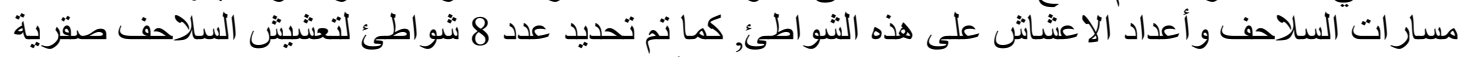
المنقار و عدد 14 شاطئ لتعشيش السلاحف الخضر اء من أجمالى الثمانية و الثلاثون شاطئ التهئ التي اشتملتها هذه الدر اسة.

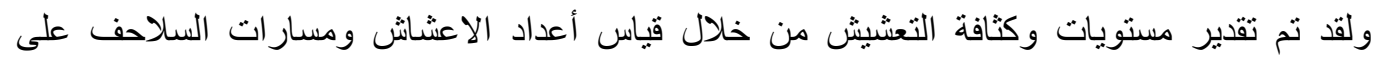

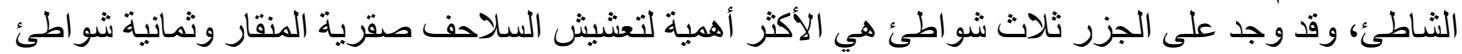

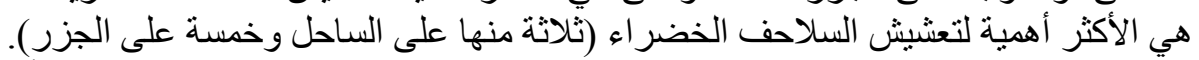

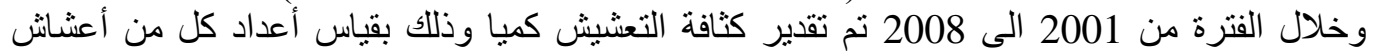

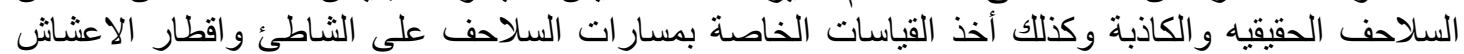

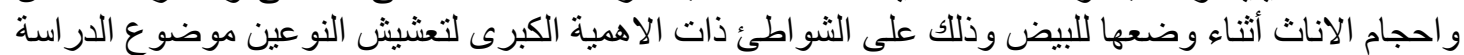

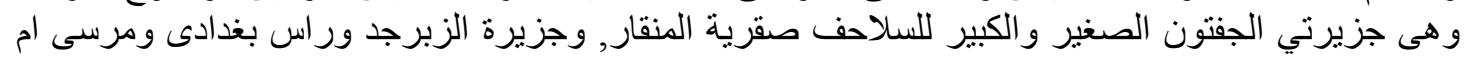

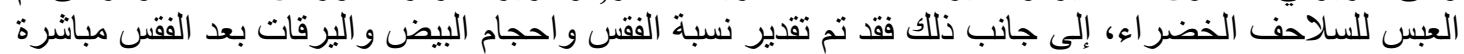

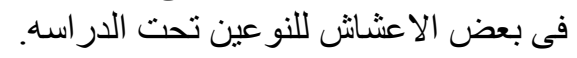

